\title{
Life Cycle Assessment of Flat Plate Solar Thermal Collectors
}

\section{Foivi-Zoi Morsink-Georgali, Angeliki Kylili, Paris A. Fokaides*}

Frederick University, School of Engineering, 7 Frederickou Str., 1036, Nicosia, Cyprus

${ }^{*}$ Corresponding author: eng.fp@frederick.ac.cy

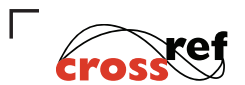

http://dx.doi.org/10.5755/j01.sace.21.4.18299
The environmental assessment of facilities and equipment used for the exploitation of renewable energy sources constitutes a major challenge of the environmental scientific community. Studies conducted in this field aim to define manufacturing alternatives which could mitigate the negative environmental impacts. The purpose of this study is the implementation of a comprehensive life cycle assessment for the definition of the environmental performance of flat plate solar thermal collectors. In terms of this study four alternative manufacturing scenarios are examined and a comparative assessment of the findings of the individual analyses is performed. The interpretation of the LCA findings leads to some useful conclusions concerning the improvement of the environmental performance of flat plate solar thermal collectors manufacturing.

Keywords: Solar thermal panels, flat plate collectors, life cycle assessment.

The ever increasing global temperature, the continued climate change in all stages and the enduring resource depletion has led inevitably to the usage of renewable energy sources and the manufacture of different devices that could help us to make a change or even to minimize what we have already caused in this planet. Sun is one of the most primarily forms of energy, and therefore the conversion of solar energy into electricity could led us in the minimization of greenhouse gasses, in energy savings, the achievement of $2020 \& 2050$ energy targets, the halt of the rising global temperature and at the end in a life concluding in a sustainable environment. Solar collectors are a kind of systems that concentrate and convert the solar power indirectly.

Life Cycle Assessment (LCA) is an effective methodology to assess the energy and environmental impacts of these energy systems during their life cycle, including manufacturing, operation and end-of-life. LCA is becoming a common way to make fair environmental comparison between materials or systems, due to its comprehensive method, which assesses and quantifies the environmental impact of a product or process over its entire life cycle, including manufacturing, operation and end-of-life. Every manufacturing process entails a consumption of energy and raw materials as well as the release of pollutants. That is the most solid reason on why a LCA is a prerequisite even for renewable energy sources. On this concept the European countries have focused their attention, considering the improvement of the eco-performances of products / services as a key point of the European environmental program. (European Union, COM 2010, 31) The accuracy of LCA results is dependent though on the method chosen, the degree of disaggregation or detail in the data, and the quality of the data itself (Crawford \& Treloar, 2004).

The aim of this study is to evaluate the environmental impact of solar collector manufacturing system by investigating alternative manufacturing scenarios. The utilization of recycled aluminum

\section{Introduction}

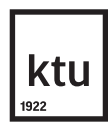

Journal of Sustainable Architecture and Civil Engineering Vol. 4/ No. 21 / 2017 pp. 41-49

DOI 10.5755/j01.sace.21.4.18299 (c) Kaunas University of Technology 
as frame and back cover, much like copper as absorber' s material allowed the comparison of their effect in the environmental performance of the final product on a "cradle to gate" approach.

The steps of this analysis are mention briefly below:

_ assessment of state of the art in LCA of a flat plate solar collector

description of the flat plate solar collector's production value chain and processing technologies

_ LCA on this collector by using Gabi software [process-by-process quantification of resource in-puts and environmental outputs]

_ analysis and discussion

This study is anticipated to provide useful insight to the scientific and environmental community concerning the methods and techniques which could lead to the mitigation of the environmental impact of the manufacturing process of solar thermal panels.

\section{Theoretical} Background

\section{Life Cycle Assessment principles}

LCA, developed by the Society of Environmental Toxicology and Chemistry (SETAC) in the 60's and defined by the ISO14040 series (ISO 14040:2006), is the most commonly used tool to determine the environmental impacts of a product or a service (Tsilingiridis et al., 2004). LCA examines material and energy inputs, emissions and other outputs throughout the life of a product (or process), including resource extraction/winning, transportation at all stages, manufacturing, assembly, energy embodied in the input of goods and services, installation and disposal/recycling (Crawford \& Treloar, 2004). The International Standards ISO 14040-14043 provides the principles, the framework and the methodological requirements for conducting LCA studies. Carrying out an LCA consists of four main phases (Wenzel et al., 2000).

\section{Goal and scope definition}

Identifying the LCA's purpose and the expected products of the study, and determining the boundaries and assumptions based upon the goal definition.

\section{- Life-cycle inventory analysis}

Quantifying the energy and raw materials inputs and environmental releases associated with each stage of production.

\section{Impact assessment}

Assessing the impacts on human health and the environment associated with energy and raw material inputs and environmental releases quantified by the inventory.

\section{Interpretation analysis}

Evaluating opportunities to reduce energy, material inputs, or environmental impacts at each stage of the product life-cycle.

LCA aims to facilitate a systems view in product and process evaluation (Joshi 1999) and can be considered as one of the major approaches in the field of industrial ecology (Guinée 2002). However, it should be mentioned that the results of LCA are not absolute, since they are focus-specific and therefore cannot be directly transferred across countries or continents; furthermore, they are dependent on system limitations, assumptions and energy/resources availability. Nevertheless, LCA results can still be exploited for the comparison of alternative technical options, systems or processes (Christoforou et al., 2016).

The international standards provide little practical guidance resulting to sources of uncertainty like:

- data inaccuracy (due to errors and imperfection in the measurements)

- data gaps or not representative data - structure of the model (as simplified model to represent the functional relationships)

different choices and assumptions

_ §system boundaries definition 


\section{Flat plate solar thermal collectors}

Solar thermal systems are an ecological way of providing domestic hot water. They are experiencing a high interest since the beginning of the last decade in many locations worldwide (Eurobserv'er, 2010). Its capacity in reducing energy load for domestic hot water is significant in locations with high irradiation level (De Laborderie et al., 2011). Solar thermal systems feed on a "clean" energy source. A comprehensive analysis of the environmen-tal performance of solar thermal collectors should consider their whole life cycle (Battisti, R., \& Corrado, 2005). A critical phase from an environmental point of view - is undoubtedly the collector production step.

The glazed flat plate collector is a heat exchanger that converts the radiant solar energy from the sun into heat energy. It collects solar energy and uses that energy for solar water-heating systems in buildings, solar space heating and process heating applications. This type tends to be more cost effective for most residential and small commercial hot water applications due to their simple design, low cost, and relatively easier installation compared to other ones (Ramlow \& Nusz, 2010).

The five main construction components of a collector are:

\section{Diaphanous solar safety glass}

The safety glass is translucent and allows high radiation yield to be received by the absorber.

\section{Aluminum absorber}

A high selective absorber is used to maximize heat collecting efficiency, converting sunlight into usable heat. The absorber is usually welded to the copper riser pipes

\section{Heater and riser pipes}

The header and riser pipes are usually brazed together in small distances to form a harp shaped heat exchanger that the solar system heat transfer fluid circulates through perfectly

\section{Insulation}

Glass wool insulation is usually used to the bottom and sides of the collector to reduce loss of heat

\section{Solid profile frame}

The solid profile frame is used to protect the absorber plate and the entire element.

Flat plate collectors can heat the fluid inside using either direct or indirect sunlight from a wide range of different angles. They also function in diffused light, which is dominant on cloudy days as it is the sur-rounding heat that is being absorbed and not the light, unlike photovoltaic cells. How hot the circulating water gets will depend mostly on the time of the year, how clear the skies are and how slowly the water flows through the collector's pipes (Dones et al., 2003)

\section{Previous studies conducted for solar thermal panels LCA}

Several studies have been conducted in the past, which addressed the environmental performance of solar thermal panels. Some studies compare the energy savings among solar collectors by calculating avoided auxiliary use (Rey-Martinez et al., 2008, Hobbi, A., \& Siddiqui, 2009) it is more common for solar thermal studies to examine ways to maximize the efficiency of the system, and increase the solar fraction This is because the embodied energy of the system is considered insignificant in comparison to the operational inputs (Tsilingiridis et al., 2004). Several studies provide a breakdown of material inputs by mass for solar thermal systems. Among them are Rey-Martinez et al. (2009) and Ardente et al. (2005). The latter provide a detailed analysis of the embodied energy and environmental impacts of a solar thermal system. This study is one of the few that examines all life cycle stages, including maintenance and installation, and gives a detailed material mass $(\mathrm{kg})$ breakdown for collectors, storage tank, and support. It is also the only one to look at direct, embodied, and feedstock energies. Kalogirou (2004) provides a highly detailed report outlining the mass of materials, embodied energy per mass of material, and carbon emissions. This study has 
drawn heavily from the above-mentioned studies in order to create a process-chain analysis and calculate carbon emissions for a solar thermal system on the test site.

\section{Methods}

\section{LCA Overview}

In terms of this study a cradle-to-gate LCA analysis was conducted. The solar panel considered was the SuperFoil ALUSEL solar collector of Johnsun Heaters Ltd (Johnsun, 2017). The data provided by the collector manufacturer cover the amount of anodized aluminum, copper, low-iron tempered solar glass, glass wool, ethylene propylene diene monomer rubber (EPDM), high-density polyethylene (HDPE), and silicone, that is contained in a collector with an aperture area of $1.32 \mathrm{~m}^{2}$ (gross area is $1.48 \mathrm{~m}^{2}$ ) and an empty weight of $21.4 \mathrm{~kg}$. The solar glass is tempered, but in contrast to the solar glass of the flat plate col-lector with a copper absorber, no anti-reflex-coating is applied. The aluminum/copper absorber has a selective coating of nickel pigmented aluminum oxide (Bluetec eta plus - an air-to-air vacuum coating process). The efficiency is $74.7 \%$. The amount of electricity, tap water, solder and factory infrastructure used for assembly of the collector, as well as the amount of generated wastewater, is adopted from the flat plate collector with a copper absorber. The LCA of solar thermal panel manufacturing was implemented based on the principles described in the ISO 14040 standard (ISO 14040:2006). To this end, the Gabi soft-ware was used to model the panel manufacturing system and to investigate its environmental performance. The Gabi database delivers full range Life Cycle Inventories ( $\mathrm{LCls}$ ), which enable the use of various impact assessment methods.

\section{LCA Goal and Scope Definition}

The goal of this study was to evaluate the environmental impact of solar collector's manufacturing sys-tem by investigating alternative manufacturing scenarios in a cradle to gate analysis. The usage of recycled aluminum as frame and back cover, much like copper as absorber's material allowed the com-parison of their effect in the environmental performance of the final product. To ensure that all the input and output from panel manufacturing are related, the analysis was performed based on a reference unit regarding the quantification of the environmental performances. The functional unit of one square meter of absorber area was used for the proper delineation of the inputs so as to be extracting the outputs.

The following manufacturing scenarios were examined:

- manufacturing of aluminum-alloy frame and _ substitution of aluminum absorber with back cover (Scenario 1) copper absorber (Scenario 3)

substitution of aluminum-alloy frame and back combination of second and third scenaricover with recycled aluminum (Scenario 2) os adjustments (Scenario 4)

\section{LCA Impact Categories}

For the purposes of this study, the CML (2001) methodology, one of the most widely used impact assessment methodologies, was employed (Laurent et al., 2014). CML method is the methodology of the Centre for Environmental Studies (CML), University of Leiden, and focuses on a series of environmental impact categories expressed in terms of emissions to the environment.

The impact categories which were examined in this study are listed below:

_ global warming potential (GWP 100 years)

acidification potential (AP)

eutrophication potential (EP)

ozone layer depletion potential (ODP, steady state)

abiotic depletion potential (ADP)

freshwater aquatic ecotoxicity potential (FAEP inf.)
- marine aquatic ecotoxicity potential (MAEP)

_ terrestric ecotoxicity potential (TEP) human toxicity potential (HTP) - photochemical ozone creation potential (POCP) 


\section{Life Cycle Inventory ( $\mathrm{LCl})$}

In Table 1 the $\mathrm{LCl}$ of the study is presented. The flow chart of the manufacturing process for Scenario 1 is also presented in Fig. 1. The main assumptions for the study $\mathrm{LCl}$ are the following:

\section{Results and Discussion}

\section{from Egypt to Cyprus (distance $958 \mathrm{~km}$ ). \\ EPDM (Ethylene Pro- pylene Diene Elasto- mer) rubber}

Aluminum back cover and aluminum frame

Based on the considered dimensions, the aluminum back cover mass was $8.4 \mathrm{~kg}$ and the aluminum frame mass was $3.6 \mathrm{~kg}$. Concerning the transportation of aluminum, this was imported

EPDM, used as a wedge between the sliding back sheet and the frame, had a mass of $0.01 \mathrm{~kg}$. The rubber is produced in Cyprus.

\section{Glasswool}

The total mass of the $5 \mathrm{~cm}$ thickness glasswool was $2.36 \mathrm{~kg}$. Glasswool is transported from Greece to Cyprus (distance $1117 \mathrm{~km}$ ).

\section{Riser}

Risers are manufactured with coper. The total mass of the risers is $4.83 \mathrm{~kg}$. Copper is imported in Cyprus from Bulgaria (Distance 1088 $\mathrm{km})$. The machine used for the piercing of the copper pipes operates with a programmable logic controller (PLC) (50W and less than 3 sec per vent, 30 sec per pipe) and compressed

\begin{tabular}{|c|c|c|c|c|}
\hline Element & Material & Mass [kg] & Process & Source \\
\hline \multirow{5}{*}{ Back cover } & \multirow{2}{*}{ aluminum } & \multirow[t]{2}{*}{8.4} & $\begin{array}{l}\text { aluminum } \\
\text { production }\end{array}$ & \multirow{5}{*}{ PE International } \\
\hline & & & rolling & \\
\hline & \multirow{3}{*}{$\begin{array}{l}\text { recycled } \\
\text { aluminum }\end{array}$} & \multirow{3}{*}{2.4} & recycling & \\
\hline & & & ingot casting & \\
\hline & & & rolling & \\
\hline \multirow{5}{*}{ Frame } & \multirow[t]{2}{*}{ aluminum } & \multirow[t]{2}{*}{3.6} & $\begin{array}{l}\text { aluminum } \\
\text { production }\end{array}$ & \multirow{5}{*}{ PE International } \\
\hline & & & extrusion & \\
\hline & \multirow{3}{*}{$\begin{array}{l}\text { recycled } \\
\text { aluminum }\end{array}$} & \multirow{3}{*}{1.04} & recycling & \\
\hline & & & ingot casting & \\
\hline & & & rolling & \\
\hline Insulation & $\begin{array}{l}\text { glass } \\
\text { wool }\end{array}$ & 2.36 & $\begin{array}{l}\text { glass wool } \\
\text { production }\end{array}$ & $\begin{array}{l}\text { Literature [Glass } \\
\text { wool] }\end{array}$ \\
\hline Risers & copper & 3.63 & copper alloy & PE International \\
\hline \multirow{3}{*}{ Headers } & \multirow{3}{*}{ copper } & \multirow{3}{*}{1.2} & extrusion & \multirow{3}{*}{ PE International } \\
\hline & & & reeling & \\
\hline & & & cutting & \\
\hline \multirow{8}{*}{ Absorber } & \multirow{4}{*}{ aluminum } & \multirow{4}{*}{0.796} & $\begin{array}{l}\text { aluminum } \\
\text { production }\end{array}$ & \multirow{4}{*}{ PE International } \\
\hline & & & rolling & \\
\hline & & & $\begin{array}{l}\text { blue eta plus } \\
\text { coating }\end{array}$ & \\
\hline & & & reeling & \\
\hline & \multirow{4}{*}{ copper } & \multirow{4}{*}{1.019} & copper production & \multirow{4}{*}{ PE International } \\
\hline & & & rolling & \\
\hline & & & $\begin{array}{l}\text { blue eta plus } \\
\text { coating }\end{array}$ & \\
\hline & & & reeling & \\
\hline \multirow{3}{*}{ Safety glass } & \multirow{3}{*}{ float flat } & \multirow{3}{*}{11.8} & $\begin{array}{l}\text { flat glass } \\
\text { production }\end{array}$ & \multirow{3}{*}{ PE International } \\
\hline & & & cutting & \\
\hline & & & hardening & \\
\hline
\end{tabular}
air that cleans the trims without to affect the conductivity of the pipes for the best soldering of pipes among them. For the soldering of the metals it is used a Milwaukee caulk (silicone) gun $\mathrm{C} 18$ PCG/400 18V, with flexible battery system.

\section{Absorber}

The absorber consists of $0.796 \mathrm{~kg}$ aluminum (1.019 kg of copper for Scenario 4). The absorber material is imported in Cyprus from Germany (Distance 2558 km).

\section{Safety Glass}

Imported from Greece, the safety glass has a mass of $11.8 \mathrm{~kg}$.

\section{Table 1}

Data inventory for the production of one solar thermal panel 
Fig. 1

Flow Chart of production process (Scenario 1)

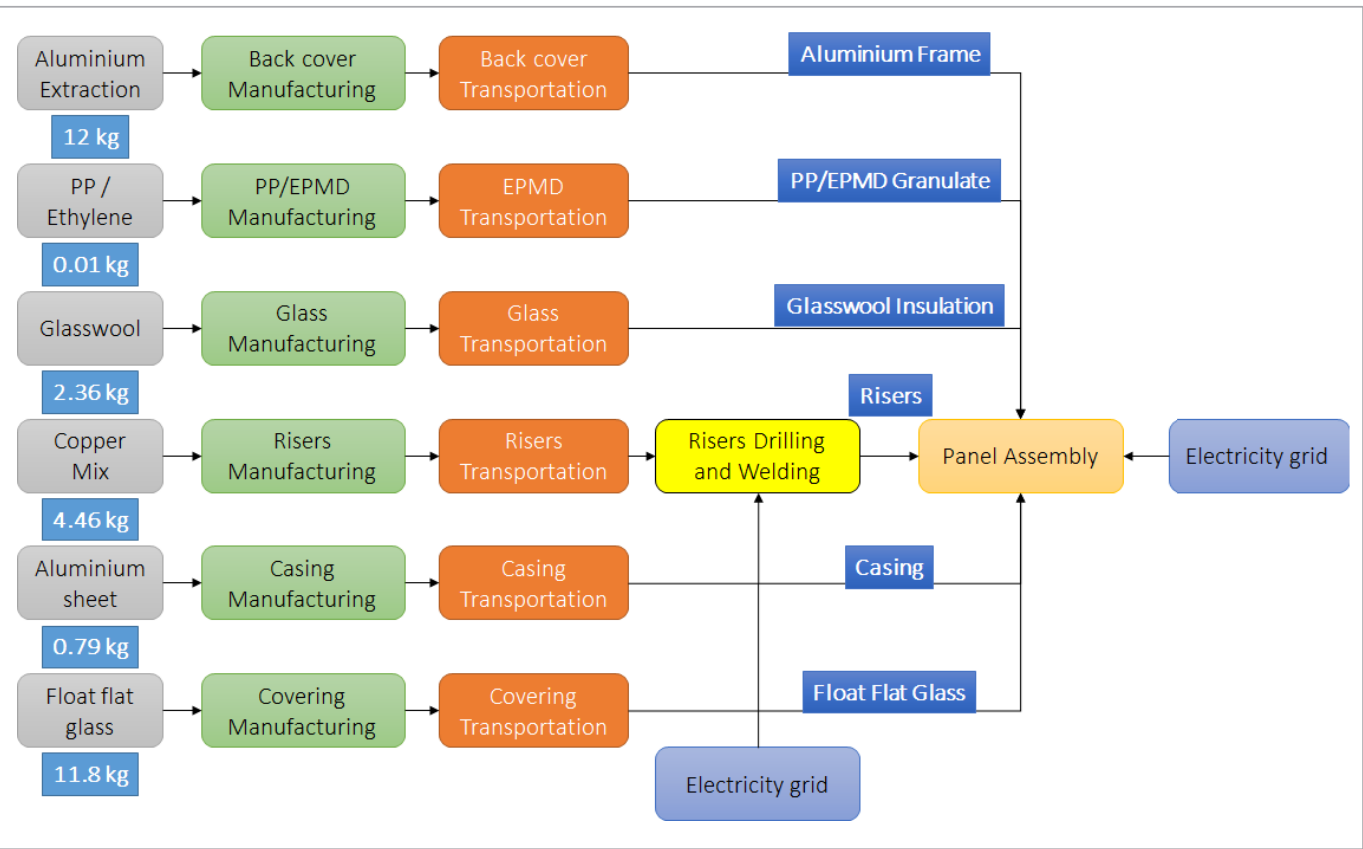

\section{Life Cycle Assessment (LCA)}

In Table 2 the flat plate solar thermal panels manufacturing system environmental impact data is provided. As it can be observed from the data, the impact categories of AD fossils (MJ), MATP ( $\mathrm{kg}$ DCB equivalent), GWP 100 (i.e. the Global Warming Potential in a time period of 100 years, measured in $\mathrm{kg}$ of equivalent $\mathrm{CO}$ ), HTP ( $\mathrm{kg}$ DCB equivalent) present the higher values in the manufacturing process of solar thermal panel. With the first glance it can be concluded that as respect to all impact categories the best environmental performance scenario is the 2 nd, which concerns the use of recycled aluminum for the cover back and the frame. Although the environmental impact of the second scenario in indicators like AD fossils, MATP and HTP is relatively high, in association to the other two scenarios these are least.

Abiotic Depletion (AD) potential is divided into two sub-categories, namely elements and fossil, and it is used to describe the reduction of non-renewable raw materials. AD elements indicator provides an evaluation of the availability of natural elements, like minerals and ores, while AD fossil indicator includes the fossil energy carriers, such as crude oil, natural gas and coal. Even though all four scenarios have almost the same quantity for AD elements (Scenarios 1 and 2 have the same result due to aluminum absorber and Scenarios 3 and 4 due to copper absorber), this is not the case for $A D$ fossils, where the Scenario 4 displays the least environmental impact.

\section{Table 2}

Solar thermal panel manufacturing systemenvironmental impactcomparative data

\begin{tabular}{|c|c|c|c|c|c|c|c|c|c|c|c|}
\hline 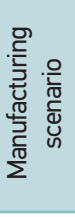 & 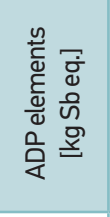 & 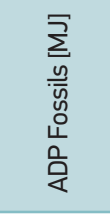 & 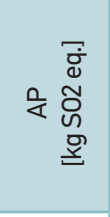 & 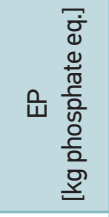 & 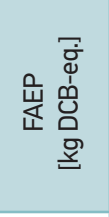 & 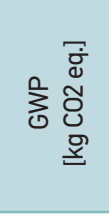 & 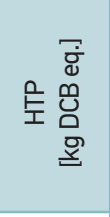 & 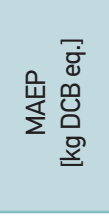 & 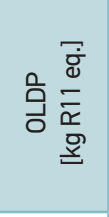 & 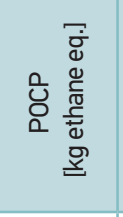 & 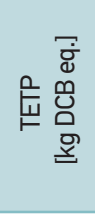 \\
\hline 1 & $2.9 \mathrm{E}-02$ & $1.3 \mathrm{E}+03$ & 5.9E-01 & 4.2E-02 & $1.7 \mathrm{E}+00$ & $1.2 \mathrm{E}+02$ & $4.5 \mathrm{E}+02$ & $2.2 \mathrm{E}+05$ & $3.1 \mathrm{E}-08$ & $2.3 \mathrm{E}-02$ & 3.0E-01 \\
\hline 2 & $2.9 \mathrm{E}-02$ & 4.1 $\mathrm{E}+02$ & $2.0 \mathrm{E}-01$ & $1.8 \mathrm{E}-02$ & $1.1 \mathrm{E}+00$ & $3.3 \mathrm{E}+01$ & $7.9 \mathrm{E}+01$ & $3.7 \mathrm{E}+04$ & 2.3E-08 & $-1.2 \mathrm{E}-03$ & $1.3 \mathrm{E}-01$ \\
\hline 3 & 3.5E-02 & $1.3 \mathrm{E}+03$ & $5.8 \mathrm{E}-01$ & 4.1E-02 & $1.7 \mathrm{E}+00$ & $1.1 \mathrm{E}+02$ & $4.3 \mathrm{E}+02$ & $2.1 \mathrm{E}+05$ & $3.0 \mathrm{E}-08$ & $2.2 \mathrm{E}-02$ & $3.0 \mathrm{E}-01$ \\
\hline 4 & 3.5E-02 & $3.9 \mathrm{E}+02$ & $1.9 \mathrm{E}-01$ & $1.8 \mathrm{E}-02$ & $1.2 \mathrm{E}+00$ & $3.0 \mathrm{E}+01$ & $5.7 \mathrm{E}+01$ & $2.6 \mathrm{E}+04$ & $2.1 \mathrm{E}-08$ & $-1.6 \mathrm{E}-03$ & $1.3 \mathrm{E}-01$ \\
\hline
\end{tabular}


A maximum AP value of $0.781 \mathrm{~kg} \mathrm{SO2}$ equivalent and a maximum EP of $0.0549 \mathrm{~kg}$ Phosphate equivalent respectively, were found for manufacturing Scenario 1. As far as the toxicity potential impact categories (i.e. FATP, MATP, TTP, and HTP) are concerned, these were examined with the CML 2001 methodology, measured in kg DCB equivalent. Specifically, with regard to the material of the back cover and frame of the solar panel, 33.94\% (FAEP), 58.23\% (TTP) lower values were found for manufacturing Scenario 2 (recycled aluminum), compared to Scenario 1 (aluminum alloy), and 88,12\% (MAETP)and 87.31\% (HTP) lower values were found for manufacturing Scenario 4 (combination), compared to Scenario 1.

The scenario with the highest environmental impact in the OLDP and GWP categories is the one involving the usage of aluminum-alloy (i.e. Scenario 1). This highlights once more the significance of the manufacturing of the back cover and frame from a different material. POCP, measured in ethylene equivalents ( $\mathrm{C} 2 \mathrm{H} 4-$ Eq.), which is an indicator of the ability of a solar panel to contribute to photochemical ozone formation, presented negative values for Scenario 4 due to the negative environmental effect from VOC emissions from the production of tropospheric 03. At high concentrations, 03 is hazardous to human health, but at lower concentrations it damages vegetation. The only way to reduce ground-level 03 is to decrease precursor emissions. In Table 3 the emissions of all four investigated scenarios are presented. According to this analysis, Scenarios 3 and 4 produce the exact same emissions in all categories. From one point of view, the high-

\begin{tabular}{l|c|c|c|c}
\hline \multicolumn{1}{c|}{ Emissions to } & Scenario 1 & Scenario 2 & Scenario 3 & Scenario 4 \\
\hline Air & $2.1 \mathrm{E}+03$ & $5.0 \mathrm{E}+02$ & $2.1 \mathrm{E}+03$ & $2.1 \mathrm{E}+03$ \\
\hline Fresh water & $1.2 \mathrm{E}+06$ & $1.0 \mathrm{E}+05$ & $1.1 \mathrm{E}+06$ & $1.1 \mathrm{E}+06$ \\
\hline Sea water & $6.9 \mathrm{E}+02$ & $9.4 \mathrm{E}+01$ & $6.6 \mathrm{E}+02$ & $6.6 \mathrm{E}+02$ \\
\hline Agricultural soil & $3.1 \mathrm{E}-06$ & $2.2 \mathrm{E}-06$ & $3.3 \mathrm{E}-06$ & $3.3 \mathrm{E}-06$ \\
\hline Industrial soil & $2.8 \mathrm{E}-04$ & $8.3 \mathrm{E}-04$ & $2.8 \mathrm{E}-04$ & $2.8 \mathrm{E}-04$ \\
\hline
\end{tabular}
est emissions -referred to air, fresh and sea water- among the rest involved in Scenario 1. On the other hand, as regards to the soil -agricultural and industrial- Scenarios 3 and 4 present the highest negative environmental impact. The lowest produced emissions are those of Scenario 2.

In order to evaluate the environmental performance of the investigated flat plate solar thermal panels, the energy balance of the end-products was estimated for each production scenario examined in this study (see Fig. 2). As it can be observed from the data, the most energy intensive

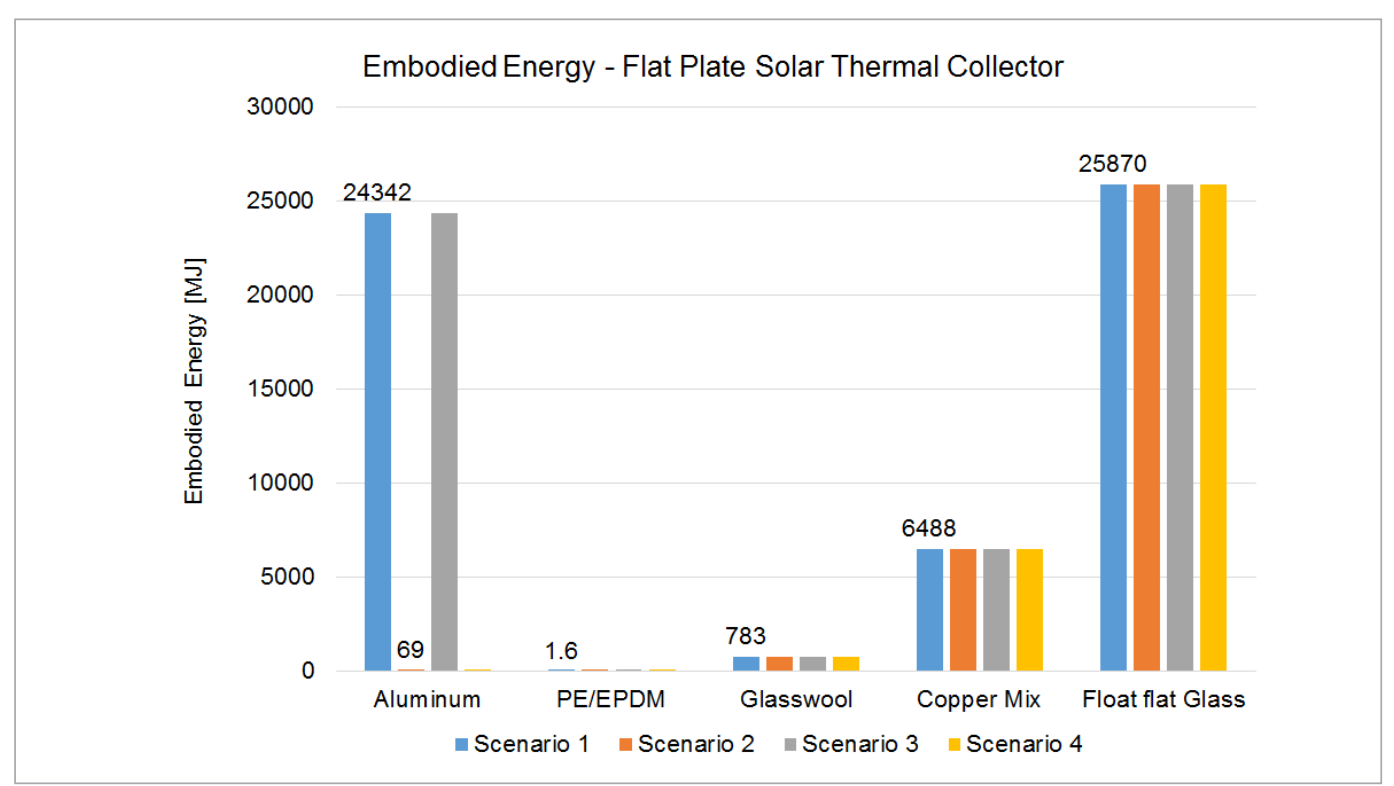

Table 3

Emissions of all four investigated scenarios

Fig. 2

Flat Plate Solar Thermal Collectors Embodied Energy 
material in Scenario 1 is the aluminum used for the back cover and the frame, and as a result that was the main rea-son examining other scenarios. Regarding Scenario 2, the results are slightly different. The energy needs for manufacturing the back cover and frame are significantly lower (99.97\%), due to the change of the material to recycled aluminum. Float flat (safety glass) use most of the energy in this scenario.

\section{Conclusions}

The scope of this study was to examine the environmental impact of different solar thermal panel manufacturing systems through a cradle to gate life cycle analysis and to provide representative data regarding the energy balance of the end-products. For this purpose, four different manufacturing scenarios were examined. In two of these, the back cover and frame of the panel were manufactured with either aluminium alloy (Scenario 1) or recycled aluminium (Scenario 2). In the third examined scenario, the absorber of the panel was manufactured from copper instead of aluminium and in the fourth scenario the combination of Scenarios 2 and 3 was assumed. Based on the results of the aforementioned scenarios, it is confirmed that the minimization of the usage of aluminium metal with recycled one can significantly affect the environmental footprint of a solar thermal panel. Particularly aluminium accounts for over $40 \%$ of the embodied energy of the end product, whereas the use of recycled aluminium results to the significant reduction of this indicator. Similarly the use of recycled back cover reduces the global warming potential of the frame from $1.2 \mathrm{E}+02$ to $3.3 \mathrm{E}+01 \mathrm{~kg} \mathrm{CO} 2 \mathrm{eq}$. The analysis also revealed that floating glass has a major contribution to the embodied energy of the panel, with over $50 \%$ of the total embodied energy. An evaluation of the results regarding the energy balance of materials assembled to a solar collector was also provided in this study, coming to terms of the recycled aluminium as a better solution than aluminium alloy. The application of the alternative metal materials in four manufacturing scenarios further allowed the evaluation of its performance in terms of its impact on the several categories examined within the CML 2001 methodology. The combination of the two adjustments together in one panel contributes to the best possible and least energy intensive scenarios.

Acknowledgment
The authors would like to address their graduate to Dr Andreas loannides, Director of Johnsun Heaters Ltd for providing of the required information for the implementation of the $\mathrm{LCl}$ of the flat plate solar thermal collector manufacturing.

\section{References}

Commission of the European Communities, Sixth environment action program of the European community, Environment 2010: our future, our choice. Communication from the Commission to the Council, COM 2010, 31 Final

Ardente, F., Beccali, G., Cellura, M., \& Brano, V. L. (2005). Life cycle assessment of a solar thermal collector: sensitivity analysis, energy and environmental balances. Renewable Energy, 30(2), 109130. https://doi.org/10.1016/j.renene.2004.05.006

Battisti, R., \& Corrado, A. (2005). Environmental assessment of solar thermal collectors with integrated water storage. Journal of Cleaner Production, 13(13), 1295-1300.

Christoforou, E., Kylili, A., Fokaides, P. A., \& loannou, I. (2016). Cradle to site Life Cycle Assessment (LCA) of adobe bricks. Journal of Cleaner Production, 112, 443452. https://doi.org/10.1016/j.jclepro.2015.09.016
Crawford, R. H. (2004). Using input-output data in life cycle inventory analysis (No. Ph. D.). Deakin University.

Crawford, R., \& Treloar, G. (2004, January). Assessment of embodied energy analysis methods for the Australian construction industry. In ANZAScA 2004: Contexts of architecture: proceedings of the 38th Annual Conference of the Architectural Science Association ANZAScA and the International Building Performance Simulation Association (pp. 415-421). University of Tasmania.

De Laborderie, A., Puech, C., Adra, N., Blanc, I., Beloin-Saint-Pierre, D., Padey, P., ... \& Jacquin, P. (2011, May). Environmental impacts of solar thermal systems with life cycle assessment. In World Renewable Energy Congress-Sweden (Vol. 57, No. 14, pp. 3678-3685). Linköping University Electronic Press, Linköpings universitet. https://doi. org/10.3384/ecp 110573678 
Eurobserv'er, Solar thermal Barometer, SYSTÈMES SOLAIRES - le journal des énergies renouvelables $N^{\circ}$ 191, June 2009,2 Solar Thermal Markets in Europe Trends and Market Statistics 2009, ESTIF, 2010

Guinée, J. B. (2002). Handbook on life cycle assessment operational guide to the ISO standards. The international journal of life cycle assessment, 7(5), 311-313. https://doi.org/10.1007/BF02978897

Hobbi, A., \& Siddiqui, K. (2009). Experimental study on the effect of heat transfer enhancement devices in flat-plate solar collectors. International Journal of Heat and Mass Transfer, 52(19), 4650-4658. https:// doi.org/10.1016/j.ijheatmasstransfer.2009.03.018

ISO 14040:2006 - Environmental management Life cycle assessment.

Johnsun Solar Heaters Ltd. http://www. johnsun-solar.com.cy/index.php?key=solar\&contentid=2. Last accessed: 20 March 2017

Joshi, S. (1999). Product environmental life-cycle assessment using input-output techniques. Journal of industrial ecology, 3(2-3), 95-120. https://doi. org/10.1162/108819899569449

Kalogirou, S. A. (2004). Environmental benefits of domestic solar energy systems. Energy conversion and management, 45(18), 3075-3092. https://doi. org/10.1016/j.enconman.2003.12.019

Kloepffer, W. (2001). Life cycle assessment in industry and business. The International Journal of Life Cycle Assessment, 6(3), 184-184. https://doi. org/10.1007/BF02978739

Koroneos, C. J., \& Koroneos, Y. (2007). Renewable energy systems: the environmental impact approach. International Journal of Global Energy Issues, 27(4),
425-441. https://doi.org/10.1504/IJGEl.2007.014865 Laurent, A., Bakas, I., Clavreul, J., Bernstad, A., Niero, M., Gentil, E., ... \& Christensen, T. H. (2014). Review of LCA studies of solid waste management systems-Part I: Lessons learned and perspectives. Waste management, 34(3), 573-588. https://doi. org/10.1016/j.wasman.2013.10.045

R. Dones, T. Heck, S. Hirschberg, Kernenergie. In: Sachbilanzen von Energiesystemen: Grundlagen für den ökologischen Vergleich von Energiesystemen und den Einbezug von Energiesystemen in Ökobilanzen für die Schweiz, Paul Scherrer Institut Villigen, Swiss Centre for Life Cycle Inventories, Dübendorf, Switzerland, 2003

Ramlow, B., \& Nusz, B. (2010). Solar Water Heating--Revised \& Expanded Edition: A Comprehensive Guide to Solar Water and Space Heating Systems. New Society Publishers.

Rey-Martínez, F. J., Velasco-Gómez, E., Martín-Gil, J., Navas Gracia, L. M., \& Hernández Navarro, S. (2008). Life cycle analysis of a thermal solar installation at a rural house in Valladolid (Spain). Environmental Engineering Science, 25(5), 713-724. https://doi.org/10.1089/ees.2007.0115

Tsilingiridis, G. M. N. K. G., Martinopoulos, G., \& Kyriakis, N. (2004). Life cycle environmental impact of a thermosyphonic domestic solar hot water system in comparison with electrical and gas water heating. Renewable Energy, 29(8), 1277-1288. https://doi.org/10.1016/j.renene.2003.12.007

Wenzel, H., Hauschild, M. Z., \& Alting, L. (2000). Environmental Assessment of Products: Volume 1: Methodology, tools and case studies in product development (Vol. 1). Springer Science \& Business Media.

\section{FOIVI-ZOI MORSINK-GEORGALI}

\section{Student}

MSc Programme in Sustainable Energy Systems

\section{Main research area}

Environmental assessment of sustainable energy technologies

\section{Address}

7, Frederickou Str., 1036, Nicosia, Cyprus

Tel. +35722394394

E-mail: st0010383@stud.frederick.ac.cy

\section{ANGELIKI KYLILI PhD Candidate}

Frederick University

\section{Main research area}

Environmental assessment of sustainable energy technologies and building materials

\section{Address}

7, Frederickou Str., 1036, Nicosia, Cyprus Tel. +35722 394394 E-mail: res.ka@frederick.ac.cy

\author{
PARIS FOKAIDES \\ Lecturer \\ School of Engineering, Frederick \\ University

\section{Main research area} \\ Computational and experimental \\ building physics, sustainable \\ energy technologies.

\section{Address} \\ 7, Frederickou Str., 1036, Nicosia, \\ Cyprus \\ Tel. +35722 394394 \\ E-mail: eng.fp@frederick.ac.cy
}

\section{About the authors}

